\title{
ІННОВАЦІЙНА СПРЯМОВАНІСТЬ РОЗВИТКУ МЕДИЧНОЇ НАУКИ
}

\author{
Л. Г. Карпінська ${ }^{1}$, О. П. Волосовець ${ }^{1}$, О. М. Кочет ${ }^{1}$, П. Р. Петрашенко르, \\ К. В. Баранніков ${ }^{1}$, А. Є. Горбань ${ }^{3}$, I. І. Шевчук ${ }^{1}$, I. О. Трубка ${ }^{1}$, \\ С. В. Уваренко ${ }^{1}$, Л. І. Закрутько \\ ${ }^{1}$ Міністерство охорони здоров'я України, \\ ${ }^{2} Д У$ “Украӥнський інститут стратегічних досліджень МОЗ Украӥни”, Київ, \\ ${ }^{3}$ ДУ “Український центр наукової медичної інформації \\ та патентно-ліцензійної роботи” МОЗ України, Київ
}

\section{INNOVATIVE ORIENTATION OF DEVELOPMENT OF MEDICAL SCIENCES}

\author{
L. H. Karpinska ${ }^{1}$, O. P. Volosovets ${ }^{1}$, O. M. Kochet ${ }^{1}$, P. R. Petrashenko ${ }^{2}$, \\ K. V. Barannikov ${ }^{1}$, A.Ye. Horban ${ }^{3}$, I. I. Shevchuk ${ }^{1}$, I. O. Trubka ${ }^{1}$, S. V. Uvarenko ${ }^{1}$, \\ L. I. Zakrutko ${ }^{3}$ \\ ${ }^{1}$ Ministry of Health Care of Ukraine, \\ ${ }^{2}$ Ukrainian Institute of Strategic Research of Ministry of Health Care of Ukraine, Kyiv, \\ ${ }^{3}$ Ukrainian Center of Scientific Medical Information \\ and Patent-Licence Provision of Ministry of Health Care of Ukraine, Kyiv
}

\begin{abstract}
Проаналізована сучасна законодавчо-нормативна база щодо пріоритетних напрямів розвитку вітчизняної науки та ії інноваційної спрямованості. Проаналізовано механізми експертної оцінки передбачуваних до розробки науководослідних проектів та затвердження їх до виконання. Наведені дані про результати виконання фундаментальних та прикладних наукових досліджень і впровадження їх у практику в 2015 р., про представлення результатів наукових розробок на наукових медичних форумах, які відбулися у 2015 р., про підготовку наукових кадрів. Акцентовано увагу на необхідності підвищення якості наукових публікацій з урахуванням вимог наукометричних баз даних. Наведені дані про участь науковців системи охорони здоров’я України у міжнародних наукових проектах. Визначені вимоги для забезпечення подальшого розвитку вітчизняної медичної науки і підвищення ії результативності та ефективності впровадження нововведень у практику охорони здоров’я України.
\end{abstract}

\begin{abstract}
The current legislative and regulatory framework for the priority areas of national science and its innovative orientation are presented. Mechanisms of peer review anticipated to develop research projects and approving them for execution are analysed. The data on the results of basic and applied research and their implementation in practice in 2015, presenting the results of scientific research in scientific medical forums that took place in 2015, the training of scientific personnel are presented. The attention on the need to improve the quality of scientific publications with the requirements of scientometric databases are accented. The data on the participation of scientists of the health system of Ukraine in international research projects are presented. The requirements for the further development of domestic medical science and improve its effectiveness and efficiency innovation into practice of health care of Ukraine.
\end{abstract}

Вступ. Розвиток та реформування національної системи охорони здоров'я потребує сталого інноваційного розвитку медичної науки в сучасних ринкових умовах. Наука, зокрема у медичній сфеpi, забезпечує відтворення та розвиток людського, інтелектуального та економічного потенціалу суспільства та є невід'ємною частиною сфери охорони здоров’я.

(с) Л. Г. Карпінська, О. П. Волосовець, О. М. Кочет та ін.
Останні роки характеризуються інтенсивним розвитком напрямів, пов'язаних із молекулярною біологією, геномікою, генною інженерією, біотехнологією, персоніфікованою медициною та ін. В області медичної науки ці напрями об’єднуються, взаємно інтегруються один в одного, що забезпечує отримання нових знань про людський організм у цілому, про його органи та системи, зокрема геном. У зв'язку з цим розвиток доказової медицини стає одним із найважливіших і найперспективніших 
напрямів як світової, так і вітчизняної медичної науки.

Законом України “Про пріоритетні напрями розвитку науки і техніки” [4] напрям “науки про життя, нові технології профілактики та лікування найпоширеніших захворювань” визначений пріоритетним на найближчий період.

Наукові дослідження, які виконуються у сфері охорони здоров’я в рамках фундаментальних та прикладних розробок за напрямами профілактичної та клінічної медицини, наукових компонентів державних цільових програм, спрямовані на розробку нових та удосконалення існуючих методів і засобів профілактики, діагностики, лікування та реабілітації при найбільш поширених, а також соціально значущих захворюваннях.

Законом України “Про пріоритетні напрями інноваційної діяльності в Україні” [6], яким визначаються правові, економічні та організаційні засади формування цілісної системи пріоритетних напрямів інноваційної діяльності, одним із стратегічних пріоритетних напрямів на 2011-2021 pр. $\epsilon$ “впровадження нових технологій та обладнання для якісного медичного обслуговування, лікування, фармацевтики”.

Результати наукових досліджень безпосередньо впливають на якість надання медичної допомоги, покращання показників здоров’я населення і діяльності закладів охорони здоров’я, попередження захворювань, забезпечення безпечного і сприятливого для здоров’я та життєдіяльності людини середовища на базі кращих медичних практик.

Основна частина. У своїй діяльності науководослідні установи та вищі медичні навчальні заклади МОЗ України (НДУ та ВМНЗ МОЗ України) керуються відповідними законами України (“Про наукову і науково-технічну діяльність” [9], “Про пріоритетні напрями розвитку науки і техніки” [4], “Про пріоритетні напрями інноваційної діяльності в Україні” [6], “Про наукову і науково-технічну експертизу” [3], “Про інноваційну діяльність” [5], “Про науково-технічну інформацію” [2]). Наукова і науково-технічна діяльність НДУ та ВМНЗ MO3 України здійснюється також відповідно до законів України “Про освіту” [1] та “Про вищу освіту" [7].

У новому Законі України “Про наукову та науково-технічну діяльність” [9] серед пріоритетів розвитку вітчизняної науки визначені: підвищення соціального статусу науковця й стимулювання мо- лодих учених; запровадження нових форм дослідницької інфраструктури та грантового фінансування в контексті інтегрування науки у європейський дослідницький простір; створення механізмів і платформ для ефективної взаємодії між представниками наукової громадськості, органів виконавчої влади, економіки та бізнесу; розширення взаємодії академічної й університетської науки та створення Національної ради з питань розвитку науки і технологій та Національного фонду досліджень, посилення антиплагіатних норм.

Водночас стан справ у галузі охорони здоров’я та медичної науки, темпи та глибина перетворень не задовольняють сучасні потреби особистості, суспільства і держави. Інформатизація, глобалізація, зміна технологій, перехід до постіндустріального, інформаційного суспільства, утвердження пріоритетів сталого розвитку, інші властиві сучасній цивілізації риси зумовлюють духовний, інтелектуальний та фізичний розвиток здорової людини як головну мету, ключовий показник та основний важіль сучасного прогресу, потребу у радикальній модернізації сфери охорони здоров'я, ставлять перед державою, суспільством завдання забезпечити пріоритетність розвитку медичної науки, першочерговість розв’язання іï нагальних проблем.

Вітчизняна медична наука протягом останніх десятиріч продовжує зазнавати на собі негативний вплив існуючого недофінансування, що призвело до зношеності наукового обладнання більшості НДУ та ВМНЗ МОЗ України.

На розвиток медичної науки в цілому значно вплинула загальна несприятлива економічна ситуація в країні і недостатність організаційного забезпечення наукових досліджень у нових економічних умовах, відсутність дієвого взаємозв'язку між МОЗ України, Національною академією медичних наук України та Національною академією наук України, певна відокремленість наукових досліджень від реальних потреб галузі протягом останніх десятиріч.

У поточному періоді спрямованість наукових досліджень установ МО3 України відповідала Програмі діяльності Кабінету Міністрів України, Стратегії сталого розвитку “Україна - 2020” [18] і програмі “Європейського Союзу “Європейська стратегія здоров’ я - 2020” та була зосереджена на розробці нових і удосконаленні існуючих медичних технологій діагностики, лікування та профілакти- 
ки найпоширеніших та соціально значущих захворювань, зокрема серцево-судинних, онкологічних, ендокринних, цереброваскулярної патології, травм тощо на засадах доказової медицини, з метою досягнення індикативного показника - підвищення середньої тривалості життя людини та запровадження стандартів медичної допомоги на основі науково обгрунтованої медичної практики.

Проекти замовлення на виконання науководослідних робіт (НДР) подавалися у рамках пріоритетних тематичних напрямів наукових досліджень і науково-технічних розробок на період до 2015 р., затверджених Постановою Кабінету Міністрів України від 07.09.2011 р. № 942 [12], середньострокових пріоритетних напрямів інноваційної діяльності загальнодержавного та галузевого рівня на 2012-2016 рр., затверджених постановами Кабінету Міністрів України від 12.03.2012 р. № 294 [13] та від 17.05.2012 р. № 397 [14].

Для участі у конкурсі приймалися заявки (запити) на фінансування НДР, затверджені експертними висновками попередньої наукової і науково-технічної експертизи НДУ чи ВМНЗ МОЗ України (відповідно до статті 14 Закону України “Про наукову і науково-технічну експертизу” [3]) з обгрунтуванням актуальності, наукової новизни та очікуваної практичної цінності проекту, відповідними експертними висновками структурних підрозділів МОЗ України, проблемних комісій МОЗ та НАМН України й головних позаштатних спеціалістів МОЗ України. Планування фундаментальних досліджень здійснювалося лише за наявності висновку про доцільність їх виконання за кожною НДР, наданого експертною радою при Національній академії наук України.

Відповідно до законів України “Про наукову і науково-технічну діяльність”, “Про пріоритетні напрями розвитку науки і техніки”, Постанови Кабінету Міністрів України від 25.08.2004 р. № 1084 “Про затвердження Порядку формування і виконання замовлення на проведення фундаментальних наукових досліджень, прикладних наукових досліджень та виконання науково-технічних (експериментальних) розробок за рахунок коштів державного бюджету” [11] за результатами конкурсу проектів наукових досліджень і розробок у сфері клінічної та профілактичної медицини було затверджено до виконання у 20 НДУ та наукових підрозділах 17 ВМНЗ МОЗ України 28 фундаментальних та 160 прикладних наукових розробок. Найбільше НДР виконувалось у Національній медичній ака- демії післядипломної освіти імені П. Л. Шупика, Національному медичному університеті імені О. О. Богомольця, Харківському національному медичному університеті та Національному інституті раку.

Фінансування проектів НДР - переможців конкурсу здійснювалося у межах визначеного обсягу видатків загального фонду Державного бюджету України.

Таким чином, у 2015 р. виконувалося 28 фундаментальних наукових досліджень у сфері профілактичної та клінічної медицини, із яких 13 НДР завершено. Результати фундаментальних досліджень висвітлені у 4 монографіях, 8 підручниках, 392 наукових статтях, 317 тезах наукових форумів, 29 методичних рекомендаціях, 57 інформаційних листах, було отримано 46 охоронних документів на об’єкти права інтелектуальної власності. Було подано 28 наукових повідомлень про наукову (науково-технічну) продукцію до Переліку наукової (науково-технічної) продукції, призначеної для впровадження досягнень медичної науки у сферу охорони здоров’я.

Тематика фундаментальних досліджень, які були завершені у 2015 р. НДУ та ВМНЗ МОЗ України, була наступною:

- визначити етіопатогенез патології сполучної тканини у постраждалих після радіаційних аварій, на підставі чого розробити патогенетичне обгрунтування лікування постраждалих;

- дослідження молекулярно-біологічних механізмів впливу аутологічної крові на організм новонароджених та малюків при хірургічному лікуванні вроджених вад серця;

- патофізіологічні механізми впливу хронічної запальної та аутоімунної реакцій, астрогліальної реактивної відповіді, окисного стресу на формування обмежень життєдіяльності у віддалені строки після кардіохірургічних втручань;

- провести порівняльний аналіз механізмів розвитку патології життєво важливих органів за експериментального судомного синдрому різної етіології і оптимізувати фармакологічні схеми його лікування;

- вивчити закономірності формування серцевосудинних уражень у хворих на антифосфоліпідний синдром та розробити диференційовані підходи до їх фармакологічної корекції;

- молекулярно-біохімічні механізми формування мітохондріальної дисфункції нейронів головного 
мозку в умовах гострої церебральної ішемії: нові мішені для нейропротекції;

- цитогенетичні механізми формування здоров’я населення та розробка заходів для його покращення;

- оптимізація комплексного лікування морфологічних ушкоджень травної, ендокринної та сечостатевої систем при цукровому діабеті;

- особливості будови органів імунної та ендокринної систем при імуностимуляції та імуносупресії;

- розробка критеріїв ефективності і безпечності фармакотерапії хворих на туберкульоз і гепатити різної етіології на підставі фармакогенетичних досліджень;

- вивчення патогенетичних особливостей розвитку поліорганної недостатності в умовах експериментальної краніоскелетної травми та пошук засобів системної корекції методами клітинної терапії.

У результаті виконання фундаментальних досліджень отримані нові знання, що вносять певний внесок у процес вивчення патогенетичних механізмів розвитку захворювань та розробку на цій основі сучасних медичних технологій.

Результати виконання 160 прикладних досліджень у галузі охорони здоров’я (із яких 54 було завершено) були висвітлені у 32 монографіях, 58 підручниках та посібниках, 1474 наукових статтях, 166 методичних рекомендаціях, 332 інформаційних листах, 1162 тезах наукових форумів, отримано 169 охоронних документів на об’єкти права інтелектуальної власності. Науковцями установ МОЗ України було розроблено 849 наукових повідомлень про наукову (науково-технічну) продукцію.

Прикладні дослідження та розробки, що виконувалися НДУ та ВМНЗ МОЗ України у 2015 р., продовжували вирішення таких актуальних проблем:

- розробка нових та удосконалення існуючих медичних технологій діагностики, лікування та профілактики найпоширеніших та соціально значущих захворювань, у тому числі серцево-судинних, онкологічних, ендокринних, цереброваскулярної патології, травм на засадах доказової медицини;

- вивчення стану здоров’я населення України та розробка пропозицій щодо його збереження;

- наукове обгрунтування комплексів медичної та санаторно-курортної реабілітації, технологій медико-соціальної експертизи і реабілітації хворих та інвалідів;
- розробка медичних технологій, спрямованих на зниження рівня професійних і виробничо обумовлених захворювань, несприятливої дії на організм факторів навколишнього середовища;

- розробка науково обгрунтованої системи комунікаційних технологій в охороні здоров'я, удосконалення інституціонального механізму адаптації законодавства України з питань охорони здоров’я до законодавства Європейського Союзу, моніторингу та оцінки ефективності реалізації реформ у системі охорони здоров’я;

- наукове обгрунтування розвитку епідемічного процесу при небезпечних та особливо небезпечних інфекціях і розробка протиепідемічних та профілактичних медичних технологій.

Пріоритетними були також наукові дослідження у сфері новітніх біотехнологій.

Оприлюднення наукових розробок у сфері охорони здоров'я було проведено на 272 наукових форумах: 9 з'їздах, 14 конгресах, 17 симпозіумах та 232 науково-практичних конференціях. Вони мають важливе значення в інноваційному процесі та безперервному професійному розвитку лікарів і провізорів.

У 2015 р. за результатами виконання НДР НДУ та ВМНЗ МОЗ України для включення до Переліку наукової (науково-технічної) продукції, призначеної для впровадження досягнень медичної науки у сферу охорони здоров'я, ведення якого передбачено спільним наказом МОЗ України та НАМН від 13.11.2013 р. № 969/97 “Про удосконалення впровадження досягнень медичної науки у сферу охорони здоров'я”, зареєстрованого в Міністерстві юстиції України 05 грудня 2013 р. за № 2068/24600 [10], було подано 877 повідомлень про наукову (науково-технічну) продукцію.

MO3 України здійснює заходи із забезпечення підготовки наукових і науково-педагогічних кадрів не тільки у розрізі окремих установ, а й в розрізі наукових спеціальностей, що забезпечить формування і підтримку визнаних наукових шкіл.

На кінець 2015 р. в НДУ та ВМНЗ МОЗ України виконувалося 659 докторських і 2868 кандидатських дисертаційних робіт, затверджено 103 докторських і 538 кандидатських дисертацій, 81 докторська і 441 кандидатська дисертації захищені у спеціалізованих вчених радах, 58 докторських і 313 кандидатських дисертаційних робіт знаходилося на розгляді у спеціалізованих вчених радах. 
Необхідно посилити роботу освітніх та наукових установ МОЗ України щодо якості наукових публікацій здобувачів вищої освіти та науковців, включення їх до видань, які входять до наукометричних баз даних, що надають великі можливості щодо визначення індивідуальної стратегії науковців та основного тренду конкретної наукової установи. Як приклад можна навести роботу Запорізького державного медичного університету, науковий часопис якого “Запорізький медичний журнал” один із найбільш цитованих з медичних видань у сучасних наукометричних базах.

Наукометричні бази даних та відповідний інструментарій допомагають показати, які наукові українські організації зараз працюють найбільш продуктивно й ефективно, оцінити, наскільки ці показники повинні вирости, щоб провідні університети могли розраховувати на місця в міжнародних університетських рейтингах, надати можливість залучати грантове фінансування, інформувати вчених про те, які напрямки досліджень розвиваються, а які вичерпані [16].

Також наукометричні бази надають інформацію про те, які українські вчені часто цитуються в Web of Science, які українські журнали зараз індексуються, і яке місце вони займають у своїх галузях. Як наголосив заступник міністра освіти та науки України М. Стріха [16]: “За версією кампанії Thomson Reuters, ми маємо близько 6000 українських публікацій на рік, але високо цитованих публікацій серед них - мало. Більшість українських наукових видань не виконують функцію інформування наукової світової спільноти про новітні важливі наукові результати. Результат своєї наукової праці потрібно розміщувати в тому журналі, де цей результат стане надбанням для світової спільноти, де на нього посилатимуться, тоді учений зможе потрапити на міжнародні консорціуми та отримати гранти”. На сьогодні в Україні існує лише 16 видань за списком Web of Science, 3 них - 5 безпосередньо видаються в Україні, інші - це переклади українських журналів, які виходять за кордоном.

Він також висловив переконання, що навіть маючи обмежені ресурси, але вибудовуючи правильну редакційну політику, можна домогтися того, щоб українські журнали увійшли до світових індексів цитування.

У 2015 р. в аспірантурі закладів та установ МО3 України навчалось 1159 осіб (668 з відривом від виробництва і 491 без відриву від виробництва).
Закінчили аспірантуру 272 особи (172 з відривом від виробництва і 199 без відриву від виробництва). Зараховано до аспірантури 342 особи (221 з відривом від виробництва і 121 без відриву від виробництва).

Прийняттям Закону України "Про ратифікацію Угоди між Україною та Європейським Союзом про участь України у програмі Європейського Союзу Горизонт 2020 - Рамкова програма 3 досліджень та інновацій (2014-2020)" від 15.07.2015 р. № 604-VIII [8] забезпечено входження України до Європейського дослідницького простору, через набуття статусу асоційованого члена Рамкової програми ЄС “Горизонт 2020”.

Так, Львівським національним медичним університетом імені Данила Галицького уже підписано угоду про співпрацю в консорціумі відповідно до правил Постанови ЄС № 1290/2013 Європейського парламенту від 11 грудня 2013 р. щодо участі в програмі “Горизонт 2020” [17]. До складу міжнародного консорціуму увійшли Лілльський університет науки та технологій (Франція), Рурський університет Бохум (Німеччина), Фрідріх-Олександра університет Ерлангену-Нюрнбергу (Німеччина), Університет Гетеборгу (Швеція), Львівський національний медичний університет імені Данила Галицького (Україна), науково-дослідні лабораторії Graphenea (Естонія), Iso medical (Франція). Консорціум був створений для участі в рамковій програмі 3 наукових досліджень та інновацій Європейського Союзу “Горизонт 2020”. Заявка від консорціуму була подана на один із тематичних напрямів пріоритету “передова наука”: “Дії Марії СклодовськоїКюрі” (ідентифікатор конкурсу - H2020-MSCARISE-2015), що спрямована на підтримку навчання, мобільності науковців та розвитку інновацій. Після конкурсного відбору заявка "Pathogen and Graphene(pang)” отримала фінансову підтримку Європейського Союзу у формі гранту.

Відповідно до Постанови Кабінету Міністрів України від 12.08.2015 р. № 579 “Про затвердження Положення про порядок реалізації права на академічну мобільність” [15] з метою забезпечення мобільності у вищих навчальних закладах затверджено Положення про порядок реалізації права на академічну мобільність. Воно створює необхідні правові механізми та гарантії для реальної міжнародної мобільності викладачів і студентів, що безумовно сприятиме зміні світогляду молодих вчених та покращить результати їх наукових досліджень. 
800 аспірантів та науковців установ МОЗ України перебували на стажуванні у провідних освітніх та наукових центрах світу (найбільше з Національного медичного університету ім. О. О. Богомольця, Івано-Франківського національного медичного університету, Вінницького національного медичного університету ім. М. І. Пирогова, Дніпропетровської медичної академії). Кількість міжнародних наукових досліджень, у яких взяли участь вчені ВНЗ та НДУ МОЗ України у 2015 р., складає 378 наукових проектів з 60 країнами світу. Понад 360 іноземних науковців у минулому році перебували на стажуванні у НДУ та ВМНЗ МОЗ України. У рамках міжнародного наукового співробітництва закладами та установами МОЗ України отримано понад 300 грантів на наукові дослідження.

Особливо сприяє підвищенню професійного рівня науковців, зокрема у сфері інноваційної діяльності, участь у міжнародних наукових форумах, ознайомлення з роботою міжнародних науковопрактичних центрів. Так, у центрі телемедицини Університетської клініки Запорізького державного медичного університету для лікарів клініки проведені вебінар та дві відеолекції з провідними фахівцями медичного факультету університету Лотарингія (Франція).

Науковці Івано-Франківського національного медичного університету брали участь у Національному виставковому конкурсі "Видатні науковопрактичні досягнення в освіті”. За результатами рейтингового виставкового конкурсу для вищих навчальних закладів акредитації та установ післядипломної освіти отримано перемогу в номінації “Електронний освітній ресурс" за створення системи електронного моніторингу та розробку інтерактивних форм навчання на основі 3D-технологій. У виставковому конкурсі в номінації “Інновації у підвищенні професійної компетентності педагогів” отримано диплом лауреата I ступеня.

Ще одним важливим напрямом діяльності НДУ та ВМНЗ МОЗ України має стати розвиток практик академічної доброчесності, зокрема належного цитування, протидія плагіату, участь у створенні МОН України національного репозитарію академічних текстів. Основною метою цієї діяльності має стати проведення освітніми та науковими установами MO3 України обов'язкової перевірки на плагіат письмових робіт усіх здобувачів вищої освіти від ліцеїста і студента до докторанта.
Для забезпечення подальшого розвитку медичної науки і підвищення результативності виконання НДР та ефективності впровадження нововведень необхідно:

- прискорити підготовку нормативно-правових актів щодо імплементації Закону України “Про наукову і науково-технічну діяльність";

- значно підвищити конкурентоспроможність результатів української медичної науки на світовому ринку наукової продукції і медичних послуг; особливий пріоритет необхідно надати оригінальним цілеспрямованим розробкам як фундаментального, так і прикладного характеру;

- продовжити оптимізацію інноваційної інфраструктури наукового потенціалу галузевої медичної науки шляхом формування раціональної мережі НДУ (в тому числі наукових установ подвійного підпорядкування), створення навчально-наукововиробничих комплексів, дослідницьких університетів, центрів колективного користування науковим обладнанням тощо;

- забезпечити перехід до вирішення нагальних науково-практичних проблем охорони здоров'я через формування відповідних регіональних, галузевих, міжгалузевих програм, що сприятиме оптимізації використання асигнувань бюджетів різних рівнів;

- включити обсяги фінансування наукової діяльності до захищених статей Державного бюджету України (витрати на медичну науку $є$ важливою інноваційною складовою соціальної сфери, зокрема сфери охорони здоров'я); впровадити принципи базового фінансування основної діяльності державних наукових установ, що фінансуються за рахунок коштів державного бюджету;

- невідкладно розробити стратегію розвитку інноваційної інфраструктури та оновлення матеріальнотехнічної бази наукових установ;

- запровадити ефективні механізми трансферу технологій та комерціалізації результатів наукових розробок у сфері охорони здоров'я;

- удосконалити інформаційну базу даних результатів наукових досліджень із зазначенням основних медичних, соціальних та економічних показників;

- підвищити соціальний статус науковця та мотивацію до наукової діяльності, що дозволить суттєво вплинути на омолодження кадрового потенціалу науки; 
- продовжити подальше впровадження принципів доказової медицини у виконання наукових досліджень та при аналізі базових показників здоров’я населення;

- удосконалити підготовку фахівців з управління інвестиційною та інноваційною діяльністю у сфері охорони здоров’я.

\section{Список літератури}

1. Закон України “Про освіту” від 23.05.1991 р. № 1060-XII (із змінами) [Електронний ресурс]. - Режим доступу : http:// zakon2.rada.gov.ua/laws/show/1060-12.

2. Закон України “Про науково-технічну інформацію” від 25.06.1993 р. № 3322-XII (із змінами) [Електронний ресурс]. - Режим доступу : http://zakon0.rada.gov.ua/ go/3322-XII.

3. Закон України “Про наукову і науково-технічну експертизу” від 10.02.1995 р. № 51/95-ВР (із змінами) [Електронний ресурс]. - Режим доступу : http://zakon. rada.gov.ua/go/51/95-вр.

4. Закон України “Про пріоритетні напрями розвитку науки і техніки” від 11.07.2001 р. № 2623-III (із змінами) [Електронний ресурс]. - Режим доступу : http:// zakon4. rada.gov.ua/laws/show/2623-14.

5. Закон України “Про інноваційну діяльність" від 04.07.2002 р. № 40-IV (із змінами) [Електронний ресурс]. - Режим доступу : http://zakon4.rada.gov.ua/laws/ show/40-15.

6. Закон України “Про пріоритетні напрями інноваційної діяльності в Україні” від 08.09.2011 р. № 3715-VI (із змінами) [Електронний ресурс]. - Режим доступу : http://zakon.rada.gov.ua/go/433-15.

7. Закон України “Про вищу освіту” від 01.07.2014 р. № 1556-VII (із змінами) [Електронний ресурс]. - Режим доступу : http:// zakon.rada.gov.ua/go/1556-18.

8. Закон України “Про ратифікацію угоди між Україною і Європейським Союзом про участь України у рамковій програмі Європейського Союзу з наукових досліджень та інновацій “Горизонт 2020” від 15.07.2015 р. № 604-VIII [Електронний ресурс]. - Режим доступу : http:// zakon5.rada.gov.ua/laws/show/604-19.

9. Закон України “Про наукову і науково-технічну діяльність” від 26.11.2015 р. № 848-VIII [Електронний ресурс]. - Режим доступу : http:// http://zakon4.rada.gov. ua/laws/show/848-19/page.

10. Наказ МОЗ України та НАМН України “Про удосконалення впровадження досягнень медичної науки у сферу охорони здоров’я” від 13.11.2013 р. № 969/97, зареєстрований у Міністерстві юстиції України 05.12.2013 р. за № 2068/24600.

11. Постанова Кабінету Міністрів України "Про затвердження Порядку формування і виконання замовлення на проведення фундаментальних наукових досліджень, прикладних наукових досліджень та виконання
Висновок. Підвищення вимог до подальшого розвитку медичної науки та підвищення результативності виконання наукових розробок $\epsilon$ обов'язковою передумовою успішної реалізації інноваційної політики у сфері охорони здоров'я, спрямованої на покращання показників здоров’я населення України.

науково-технічних (експериментальних) розробок за рахунок коштів державного бюджету” від 25.08.2004 p. № 1084 (із змінами) [Електронний ресурс]. - Режим доступу : http:// zakon.rada.gov.ua/laws/show/1084-2004-п.

12. Постанова Кабінету Міністрів України "Про затвердження переліку пріоритетних тематичних напрямів наукових досліджень і науково-технічних розробок на період до 2015 р.” від 07.09.2011 р. № 942 (із змінами) [Електронний ресурс]. - Режим доступу : http:// zakon2. rada.gov.ua/laws/show/942-2011-п.

13. Постанова Кабінету Міністрів України “Деякі питання визначення середньострокових пріоритетних напрямів інноваційної діяльності загальнодержавного рівня на 2012-2016 роки” від 12.03.2012 р. № 294 (із змінами) [Електронний ресурс]. - Режим доступу : http:// zakon2.rada.gov.ua/laws/show/294-2012-п.

14. Постанова Кабінету Міністрів України “Деякі питання визначення середньострокових пріоритетних напрямів інноваційної діяльності галузевого рівня на 2012-2016 роки” від 17.05.2012 р. № 397 (із змінами) [Електронний ресурс]. - Режим доступу : http:// zakon2. rada.gov.ua/laws/show/397-2012-п.

15. Постанова Кабінету Міністрів України “Про затвердження Положення про порядок реалізації права на академічну мобільність” від 12.08.2015 р. № 579. [Електронний ресурс]. - Режим доступу : http:// zakon5. rada.gov.ua/laws/show/604-19.

16. Стріха М. Наукометричні бази даних як інструментарій реалізації наукового та науково-технічного потенціалу в контексті інтеграції до європейського наукового простору. Семінар, Київ, 4 грудня 2015 р., вітальне слово [Електронний ресурс]. - Режим доступу : http:// everum. org.ua/files/.../Strikha_vitalne-slovo.pd...

17. Угода між Україною і Європейським Союзом про участь України у програмі Європейського Союзу Горизонт 2020 - Рамкова програма з досліджень та інновацій (2014-2020) від 20.03.2015 р. [Електронний ресурс]. - Режим доступу : http:// zakon3.rada.gov.ua/laws/ show/984_018.

18. Указ Президента України “Про Стратегію сталого розвитку “Україна-2020”” від 12.01.2015 р., № 5/2015 [Електронний ресурс]. - Режим доступу : http:// zakon. rada.gov.ua/go/5/2015. 